\title{
Saline Agriculture in the 21st Century: Using Salt Contaminated Resources to Cope Food Requirements
}

\author{
Bruno Ladeiro \\ MAP-BioPlant, Porto, Portugal \\ Correspondence should be addressed to Bruno Ladeiro, brunoc.f.ladeiro@hotmail.com
}

Received 2 December 2011; Accepted 1 August 2012

Academic Editor: Conceição Santos

Copyright () 2012 Bruno Ladeiro. This is an open access article distributed under the Creative Commons Attribution License, which permits unrestricted use, distribution, and reproduction in any medium, provided the original work is properly cited.

With the continue increase of the world population the requirements for food, freshwater, and fuel are bigger every day. This way an urgent necessity to develop, create, and practice a new type of agriculture, which has to be environmentally sustainable and adequate to the soils, is arising. Among the stresses in plant agriculture worldwide, the increase of soil salinity is considered the major stress. This is particularly emerging in developing countries that present the highest population growth rates, and often the high rates of soil degradation. Therefore, salt-tolerant plants provide a sensible alternative for many developing countries. These plants have the capacity to grow using land and water unsuitable for conventional crops producing food, fuel, fodder, fibber, resin, essential oils, and pharmaceutical products. In addition to their production capabilities they can be used simultaneously for landscape reintegration and soil rehabilitation. This review will cover important subjects concerning saline agriculture and the crop potential of halophytes to use salt-contaminated resources to manage food requirements.

\section{Human Population Growth and Agriculture Challenges in the 21st Century}

It is estimated that in November 2011, the mankind has reached the 7 thousand million people, and the United Nations (2008) predicted a population increase up to 8.01 thousand million people in 2025. This represents a duplication of human population in approximately 50 years. So, agriculture strategies for feeding all people represent one of the most important challenges in the 21 st century. Therefore, there is enormous demographic and economic pressure to rise, within the next 40 years, leading to an increase of the crop production by about $50 \%$ years in a sustainable manner to fulfil the world food necessities [1, 2]. Some other facts are aggravating this demand, namely, (a) the increase of land occupation for biofuel supply that deviates arable soils from food crops [3], (b) the challenges posed by increasing occasional episodes of extreme environmental conditions and even natural disasters often associated with the generally called "climate change events", (c) some excesses in soil pressure posed by postgreen revolution practices; (d) the raise of soil degradation and/or the increase of saline soils is growing dramatically, reducing the area of arable land. The duality faced by mankind concerning food supply was summarized by Rudel [4] stating "our ability to supply the growing global demand for food, fiber, and fuel, while maintaining a landscape able to provide a full suite of environmental services, hinges on our ability to produce more on less land. This pressure is particularly high in developing countries".

Agriculture is the first human activity and represents the major use of land across the world [5]. Agriculture can be defined as an "artificial management to enhance the food value of cultivated land" and represents "the major land use across the globe" [6]. Some emerging strategies to enhance food production involve, for example, increasing yield and cropping intensities, genetic modification [7] which may involve converging strategies of seed and germplasm preservation and improvement [2], and/or developing strategies for use of contaminated or dried soils, meanwhile abandoned as nonproductive.

This increase is particularly emerging in developing countries that present the highest population growth rates, and often the high rates of soil degradation (the Mediterranean Basin [8], Australia, Central Asia, and the Middle East and North of Africa). This pressure is so important that it is 
considered in the United Nations Millennium Development Goals [9]. In 2004 the Food and Agriculture Organization of the United Nations (FAO) estimated that there was 852 million food-deprived people worldwide in 2000-2002, with being the most critical places the sub-Saharan Africa and Southern Asia. However, in 2004, FAO also highlighted that despite in most places these hunger issues translate a real lack of food and deficient agricultural techniques. This problem is however the convergence of more complex problems [5]. This is evident by the statistical data pointing to approximately 9 million hungry people in industrialized countries where in theory there is no lack of food [10]. In 2008, FAO expected an increase of food requirements by $20 \%$ in developed countries and $60 \%$ in developing countries.

It is therefore recognised that food requirements are increasing quicker than crop production, and researchers and politicians increasingly highlight the urgent need to improve alternative agricultural strategies $[5,6,11,12]$. In other words, to produce more and better it is necessary to invest in better technology within the scopes of the Millennium Development Goals strengthening practices leading to sustainable agriculture without destroying lands and natural resources [5].

Despite all these emerging food problems, in 2011 FAO reported a study highlighting the losses occurring along the entire food chain suggesting that roughly one-third of food produced for human consumption is lost or wasted globally, which amounts to about 1.3 billion tons per year. In this study, FAO revealed that much more food is wasted in the industrialized world than in developing countries, estimating a per capita food waste by consumers in Europe and NorthAmerica of 95-115 kg/year, while this figure in Sub-Saharan Africa and South/Southeast Asia is only 6-11 kg/year.

The causes of food losses and waste in low-income countries are mainly connected to financial, managerial, and technical limitations in harvesting techniques, storage, and cooling facilities in difficult climatic conditions, infrastructure, packaging, and marketing systems. While in mediumand high-income countries food is to a significant extent wasted at the consumption stage, meaning that it is discarded even if it is still suitable for human consumption.

This way, FAO, [13], states that one of the first mean to cope with world food requirements is to also promote food loss reduction which alone has a considerable potential to increase the efficiency of the whole food chain. It is important to emphasise that the reducing food losses should not be a forgotten priority.

Agriculture improvement and adjustment to the 21st challenges also needs to take into consideration the type of land and water available $[11,14]$.

The area of irrigated land increased enormously, between 1960 ' and 1980's decades. Irrigation schemes cover only 15\% of the cultivated land worldwide, though it contributes with two-third of the world's food production [15]. It is also estimated that irrigation limits production in approximately 600 million hectares of "potentially suitable arable land" [11]. Taken together these data, one must be careful on predicting agriculture improvement in quantity and quality. However, some interesting work has been done using halophytes to complement agriculture needs $[16,17]$.

It is estimated that the agricultural production increase will need around $202 \times 10^{6}$ ha of arable soil in developing countries, but only approximately $93 \times 10^{6}$ ha seem available $[14,18]$. These data support the need to develop strategies of sustainable agriculture contrarily to what it should be expected if real sustainable agriculture practices dominated. Millions of ha of agricultural land are lost every year, mostly during the last 50-60 years of agricultural development (due to, e.g., unsustainable irrigation practices, excessive use of fertilizers, soil contamination, urban pressure, climate changes). This issue was well addressed by the USA Department of Agriculture [19] which estimated that approximately 10 million ha/year of arable soils are lost in the globe.

Fortunately, it is increasing the number of countries that subscribe the principles inherent of sustainable development and address the Millennium Development Goals, so pressure to use sustainable strategies is rising (e.g., soil and water conservation), despite the increasing pressure for food supply and urbanization.

\section{Insufficient Freshwater, Salt Contamination, and Soil Degradation}

Despite it may be considered as having an ubiquitous distribution in all the continents of the world, most of the arid and semiarid regions are located in developing countries [20]. These problems also are present in regions of the United States of America, Australia, Israel, or the Mediterranean Basin [21], and some of these countries have long tradition in circumventing soil degradation using that land for agriculture. For example, in the USA a large amount of waste land is being used for fields biodiesel plant production. In Australia, on the other hand, a major problem arises with dry land salinity due to rising water tables resulting from clearing the original native vegetation due to changing the type of plant population [15]. On counterpart, other countries, like Israel, possess crop production practices with unconventional water resources irrigation, and the use of brackish water deserves particular attention. Also, in Tunisia strong investigations were addressed to this thematic $[22,23]$ and one can find agriculture practices based in alternative plant species, most of them are halophytes, which are able to tolerate high temperatures and/or low water availability.

Salinity is one of the most widespread soil degradation processes on the Earth. Soil salinisation affects an estimated 1 to 3 million hectares in Europe, mainly in the Mediterranean countries. It is regarded as a major cause of desertification and therefore is a serious form of soil degradation being salinisation and sodification among the major degradation processes endangering the potential use of European soils. For instance, in Spain 3\% of the 3.5 million hectares of irrigated land is severely affected, reducing markedly its agricultural potential while another $15 \%$ is under serious risk. 
Other examples of salt-affected soil in Europe are the Caspian Basin, the Ukraine, and the Carpathian Basin (Hungary) [24].

The availability of freshwater is a major limiting factor in sustainable agriculture. The decrease of water availability is found in these developing regions of burgeoning population pressure, and limits the area of arable land and crop production for these people. As stated by Galvani [5], when it comes to extreme environments, such as arid and semiarid areas, pressure must be put in major adjustments in alternative agriculture [25].

\section{Soil and Water Availability and Saline Agriculture}

An innovative strategy for enhancing land and water availability is the use of salted soils and salted water, in a strategy designated as saline agriculture. This strategy is not new, as, for example, the use of seawater for crop production in coastal deserts has already been suggested in the last three decades [26-29].

This way, a possible definition for saline agriculture can be as follows.

Profitable and improved agricultural practices using saline land and saline irrigation water with the purpose to achieve better production through a sustainable and integrated use of genetic resources (plants, animals, fish, insects, and microorganisms) avoiding expensive soil recovery measures [30].

The saline water that may be used in halophyte crop irrigation can be, for example, seawater, salt-contaminated phreatic sheets, brackish water (from e.g., Estuaries), drainage water from other plantations irrigation, drainage water from humanized areas, for example, sewage [31, 32], or even water derived from aquaculture waste [33]. It was suggested that around half of the irrigation systems are susceptible to salt contamination or waterlogging, probably due to low quality of used water, leaching, and rising water tables [34]. It is therefore clear that, facing the human population pressure, the technological advances, and the increase of salinized soils and reduction of arable land usable by conventional agriculture, the use of these salinized soils in alternative agriculture may be regarded as a strategy to cope with food demand [17].

\section{Saline Agriculture: An Opportunity for Saline Soils Use}

Soil salinization has been worldwide recognized as being among the most important problems for crop production in arid and semi-arid regions [35]. As reported above, some of the emerging regions in risk of increasing levels of salinization of their soils are, for example, the Mediterranean Basin [36], Australia, Central Asia, the Middle East, and Northern Africa [32, 35].

Soil salinization has numerous origins, namely, natural causes provoked by, for example, the microscopic salt particles carried by the wind to inland from the oceans, or, as discussed above, some anthropic causes (secondary salinization) [32], among which irrigation water quality is one of the most important.

The use of salinized land through drainage/irrigation without using high-quality water, but instead also some salinized water, may be, therefore, the solution but demands exploration of the potential of halophytes as new emerging crops and changing mankind habits to incorporate this new crops in daily diet [25].

There is a need for more studies on the potential use of halophytes in saline agriculture and their use and incorporation in the consumers' diet. Also, the adequate conditions for increasing to industrial levels the halophyte species production (e.g., physiological studies, organoleptic and nutritional properties, etc.) deserve more attention. As stated by Koyro et al. [37] there are some requisites for the selection of tolerant plants with promising yields and characteristics that make them interesting as crops in saline agriculture: (a) screen of literature for their natural habitats, and so forth; (b) after selecting the species, determining the salinity threshold [15].

For halophytes succeed as irrigated crops, four basic conditions must be gathered:

(1) high yield potential; (2) the irrigation needs must not exceed the conventional crops and be harmless to the soil; (3) the products from halophyte crops must be able to replace the conventional crop products; (4) high-salinity agriculture must be applicable to the existing agricultural infrastructure [38].

\section{Which Halophyte Crops Can We Use?}

The potentiality of using halophytes in saline agriculture has been explored in the last decades. The use of halophytes in commercial cultures/exploitation, though still limited, is already being applied for some species. Also, the project "Greening Eritrea" from the Seawater Foundation [39] represents an example of how to convert a desertified region into a useful soil.

Halophytes can be improved into new, salt-resistant crops, or used as a source of genes to be introduced into conventional crop species that in general have their economical production decreased as soil salt levels increase. We'll discuss here some of the potential of halophytic species to use as emergent or already used crops in arid and semiarid regions, in a perspective of sustainable development. The sustainable use of halophytes has multiple purposes as stimulating productive ecosystems and regreening degraded areas. About 2,600 halophytic species are known and only few are extensively studied for their potential in agriculture and as biological resources with economical potential as sources of oils, flavours, gums, resins, oils, pharmaceuticals, and fibbers [5], or with environmental potential for protection and conservation of ecosystems (e.g., improvement of soil structure and fertility, habitat for wildlife, source of biomass for the production of biodiesel) $[40,41]$.

We'll discuss below some of these species. 
5.1. Food Yielding Halophytes. Aster tripolium (also known as Sea Aster or Sea Spinach) belongs to the family of the Asteraceae (Compositae). This Northern European plant, present in salt marches and estuaries, is very productive and can be cut several times with a regrowth of young shoots every 3-4 weeks. This is a familiar plant in The Netherlands since it was known as a famine food during harsh times and has become a delicacy nowadays. According to Brock et al. [42], Aster tripolium grows in temperate regions in its natural form, close to the coast mainly in the salt meadows. Also, some interesting research is being conducted concerning the response of Aster tripolium and Puccinellia maritima to atmospheric carbon dioxide enrichment and their interactions with flooding and salinity [43].

Salicornia bigelovii (Chenopodiaceae) is a very wellstudied species. As a typical halophyte it is a succulent (having CAM metabolism) plant being cultivated for its oilseed (both for human and animal use) and straw. The residual seed meal is very rich in protein (approximately 33$34 \%$ crude protein). This oilseed halophyte has a yield and seed quality similar to the soybean, reaching yields of $2 \mathrm{t} / \mathrm{ha}$ of seed containing $28 \%$ oil and $31 \%$ protein [38]. In fact, field trials with Salicornia bigelovii conducted in Puerto Penasco, Mexico (a coastal desert environment), demonstrated a production of $18 \mathrm{t} / \mathrm{ha}$ of biomass and $2 \mathrm{t} / \mathrm{ha}$ of seed over a 200-day growing cycle [18] in which the seed contained $31 \%$ protein and $28 \%$ oil rich in polyunsaturated fatty acids (being the linoleic acid 74\% of the total). The growth rates of animals fed with Salicornia bigelovii are equivalent to those fed with conventional forages on equal amounts such as alfalfa and wheat straw [18].

5.2. Oilseeds. Seeds of various halophytes, such as Suaeda fruticosa, Arthrocnemum macrostachyum, Salicornia bigelovii, S. brachiata, Halogeton glomeratus, Kochia scoparia, and Haloxylon stocksii possess a sufficient quantity of high quality edible oil with unsaturation ranging from $70-80 \%$. Seeds of Salvadora oleoides and S. persica contain 40-50\% fat and are a good source of lauric acid-a potential substitute for coconut oil.

Also Diplotaxis tenuifolia is a promising species for saline agriculture, as it lives naturally in saline/dry ecosystems, or with strong influence of sea. This plant has a potential for food (salads) and forages. Diplotaxis tenuifolia exposed to salt showed halophyte-like behaviour similar to those of known halophyte plants as Cakile maritima [44] for example or fodder beet [45]. In a recent study by Guerra [46], Diplotaxis plants survived, grew, and reproduced in all salinity up to $300 \mathrm{mM} \mathrm{NaCl}$, despite a small growth reduction was found in the higher concentration, with good values of growth at $100 \mathrm{mM}$ and with no loss of nutritional value. This suggests that this species has high potential in large scale production of salt water/soils.

Diplotaxis L. (DC.) genus is original from the Mediterranean Basin in dry, nutrient-rich, and sandy soils [47, 48], despite nowadays is relatively distributed around the world $[49,50]$. It can be grown with other halophytes as Cakile maritima in dunes and in road verges usually at a small distance from the sea [46]. Some studies have been developed with this species, for example in The Netherlands and in Portugal. This last has a coast with unique characteristics, potential use of large-scale production of this and other halophytes, and opening perspectives for an emerging market opportunity.

5.3. Fuel Wood and Timber. More than a billion people in developing countries rely on wood for cooking and heating. Quite often fuel wood is obtained from salttolerant trees and shrubs, which may include species of Prosopis, Tamarix, Salsola, Acacia, Suaeda, Kochia, Capparis, Casuarina, Pithecellobium, Parkinsonia, and Salvadora. In addition species like Dalbergia sissoo, Pongamia pinnata, Populus euphratica, and Tamarix spp. could provide goodquality wood. In coastal areas the mangroves species of Rhizophora, Ceriops, Avicennia and Aegiceras are good fuel woods and also contribute to charcoal production.

On the other hand, the agricultural applications on biofuels to cope with the global energy requirements have been increasing since high oil prices are creating new markets for agricultural commodities that can be used as feedstock for the production of bio-fuels. This way, bio-fuels are being promoted as contributing to a wide range of policy objectives, as providing greater energy security with regard to liquid fuels, increasing rural incomes, lowering greenhouse gas emissions, and providing economic opportunities for developing countries [51].

Fuels such as biodiesel can be produced from biomass ranging from cow manure to wood chips. The advantage of developing biofuel from halophytes as opposed to other types of biomass is that saltwater plants are not dependent on fresh water, which is in increasingly short supply, and can instead be irrigated using plentiful seawater supplies.

Suitable areas around the world for cultivating halophytes include the Sahara desert, Western Australia, Southwest USA, parts of the Middle East, and parts of Peru. Scientists claim that an area smaller than the Sahara desert could yield enough biomass to replace the world's fossil fuel requirements. Furthermore, in the case of halophyte production, as these plants are grown in the desert, they will produce a cooler, wetter, land surface, which could lead to rainfall in areas of the world where rainwater is in short supply [52-54].

This way, the innovation and development of biofuels and the controversies around the sustainability of conventional crops as a feedstock for biofuel will likely help halophytes to get timely focus and advantage since the most currently used biofuel sources are conventional crops such as corn, sugar cane, rape oilseed, and palm oil and do not meet for most of the sustainability related issues. Specific examples include bioethanol, made from sugar and starch crops, and biodiesel, made from vegetable oils, animal fats, and other recycled greases.

Aspects such as competition with food, land use, energy efficiency, pressure on other important resources including freshwater, rain forest, and in some cases political instability are issues of ongoing controversy around conventional 
biofuel which in turn can lead to an increase on food prices $[53,55,56]$.

5.4. Source of Chemicals. A kind of soda is obtained in large quantities from Suaeda, Salicornia, Salsola, and Haloxylon species, used in soap making and in glass industry. Seeds of Annona glabra are a source of insecticide [57].

5.5. Ornamental. Many halophytes are useful ornamentals; these include among others Aster tripolium, Limoniastrum monopetalum, Batis maritima, Tamarix nilotica, Tamarix amnicola, Cistanche fistulosum, Atriplex halimus, Sesuvium portulacastrum, and Noronhia emarginata [57].

5.6. Environmental Protection. Some species of halophytes can give an important contribute to the coastline protection and restoration of coastal ecosystems such as Spartina alterniflora, Spartina maritime, and Avicennia marina [58, 59]. Research is being undertaken to explore the potential of Avicennia germinans (black mangrove) to restore coastal and back-barrier salt marshes by taking advantage of the plants woody structure and extensive root system, providing sustainability and habitat [60].

\section{Environmental and Economic Impact of Saline Agriculture}

The economic analysis of saline water irrigation has three main aspects: (1) concerning the reclamation of saline and sodic soils preceding cultivation, (2) the constant use of saline water for irrigation and, (3) the reuse of drainage water for irrigation and the drainage installations [61].

According to a governmental report on "Saline agriculture farmer participatory development project in Pakistan" performed between 2002 and 2008 [30], the impact on the economy and environment was demonstrated.

In regard to the economic benefits, tree plantations are sustainable sources of raw materials required for a variety of industries, for example, pulp or paper, match manufacturing, sports goods, panel products, furniture timber, plywood, saw wood, fiberboard, and fuel wood. Vast quantities of dung can be saved by using fuel wood from plantings, enriching agricultural fields.

Concerning the environmental management impact, trees can be an important help to recover salt-affected land. Vegetation over saline soils tends to decrease salt concentration in the top soil due to increased infiltration and reduced capillary rise of water. This approach can allow farmers to get instant economic returns by growing field crops and also immediate economic benefits from saline wasteland with the help of trees. Such planting is preferred to various expensive engineering methods since it is cheaper and lasting. The vital impact of trees on the microclimate, soil erosion, and floods is well known. Moreover, large plantations create more favorable conditions to obtain rainfall.

An additional and interesting advantage demonstrated on this report is the ability of the trees to act as scavenging pollutants by removing water condensation nuclear particles and reducing fog containing gases harmful for life since the branches, leaves, and stems filter and precipitate dust (carried by the wind) [30].

Saline agriculture can also be a potential strategy for reducing $\mathrm{CO}_{2}$ in the atmosphere in degraded salt-affected areas. Other studies refer the use of halophyte crops to reclaim saline soils [62] since these plants can reduce the salt content of soil over time [63].

The environmental impact assessment (EIA) needs equally to concentrate on means in which positive impacts can be enhanced and negative impacts mitigated [11].

Yamaguchi and Blumwald [12] consider the "identification of key genetic determinants of stress tolerance" a precondition to the knowledge expansion on salt tolerant crops. These same authors consider two different genetic approaches, first the exploitation of natural genetic variations through marker-assisted breeding and second the generation of transgenic plants, a very popular subject that is being currently addressed by researchers. In fact, the use and improvement of conventional and molecular breading (as well as molecular genetic modification-GM) are subjects of research to adapt our existing food crops to increasing temperatures, decreased water availability in some places and flooding in others, rising salinity [64], and changing pathogen and insect threats [65]. An environmental and important good of such research is to increase the efficiency of crops nitrogen uptake and use, due to nitrogenous compounds in fertilizers being the main contributors to waterway eutrophication and greenhouse gas emissions [64].

\section{Conclusion and Future Perspectives}

The increase in nutrient demand by the prosperous society and the decreasing availability of arable land and freshwater lead to the problem of agriculture sustainable development. With these perspectives, saline agriculture is coming up as an emerging role.

In the future this agricultural area may be of extreme importance in Mediterranean countries due to the increasing soil degradation in some regions and to their geographic and climatic conditions [46].

Without a comprehensive and long-term strategy adaptable to the prevailing economic, climatic, social, as well as edaphic and hydrogeological conditions, it is not considered possible to meet the future challenges of irrigated agriculture using poor-quality water.

\section{References}

[1] N. Borlaug, "Feeding a Hungry world," Science, vol. 318, no. 5849, pp. 318-359, 2007.

[2] F. Guillon, C. Larré, F. Petipas et al., "A comprehensive overview of grain development in Brachypodium distachyon variety Bd21," Journal of Experimental Botany, vol. 63, no. 2, pp. 739-755, 2012.

[3] A. G. Prins, B. Eickhout, M. Banse, H. van Meijl, W. Rienks, and G. Woltjer, "Global impacts of European agricultural and biofuel policies," Ecology and Society, vol. 16, no. 1, p. 49, 2011. 
[4] T. K. Rudel, L. Schneider, M. Uriarte et al., "Agricultural intensification and changes in cultivated areas, 1970-2005," Proceedings of the National Academy of Sciences of the United States of America, vol. 106, no. 49, pp. 20675-20680, 2009.

[5] A. Galvani, "The challenge of the food sufficiency through salt tolerant crops," Reviews in Environmental Science and Biotechnology, vol. 6, no. 1-3, pp. 3-16, 2007.

[6] S. M. Howden, J. F. Soussana, F. N. Tubiello, N. Chhetri, M. Dunlop, and H. Meinke, "Adapting agriculture to climate change," Proceedings of the National Academy of Sciences of the United States of America, vol. 104, no. 50, pp. 19691-19696, 2007.

[7] T. J. A. Bruce, "GM as a route for delivery of sustainable crop protection," Journal of Experimental Botany, vol. 63, no. 2, pp. 537-541, 2012.

[8] R. Choukr-Allah, Introduction Advanced Course on Halophyte Utilization in Agriculture, 1993.

[9] http://www.un.org/millenniumgoals/.

[10] Food and Agriculture Organization, Monitoring progress towards the World Food Summit and Millennium Development Goals, Food and Agriculture Organization, Roma, Italia, 2004.

[11] Food and Agriculture Organization, "The use of saline waters for crop production,” Tech. Rep., Food and Agriculture Organization, Rome, Italy, 1992.

[12] T. Yamaguchi and E. Blumwald, "Developing salt-tolerant crop plants: challenges and opportunities," Trends in Plant Science, vol. 10, no. 12, pp. 615-620, 2005.

[13] Study conducted for the International Congress SAVE FOOD! at Interpack 2011 Düsseldorf, Germany-Extent, Causes and Prevention-by Jenny Gustavsson, Christel Cederberg Ulf Sonesson, Swedish Institute for Food and Biotechnology (SIK) Gothenburg, Sweden and Robert van Otterdijk, Alexandre Meybeck, FAO, Rome, Italy, 2011.

[14] M. A. Khan and N. C. Duke, "Halophytes-a resource for the future," Wetlands Ecology and Management, vol. 9, no. 6, pp. 455-456, 2001.

[15] R. Munns, "Comparative physiology of salt and water stress," Plant, Cell and Environment, vol. 25, no. 2, pp. 239-250, 2002.

[16] L. Bernstein, "Effects of salinity and sodicity on plant growth," Annual Review of Phytopathology, vol. 13, pp. 295-312, 1975.

[17] V. P. S. Shekhawat, A. Kumar, and K.-H. Neumann, "Bioreclamation of secondary salinized soils using halophytes," in Biosaline Agriculture and Salinity Tolerance in Plants, pp. 147154, 2006.

[18] E. P. Glenn, L. F. Pitelka, and M. W. Olsen, "The use of halophytes to sequester carbon," Water, Air, and Soil Pollution, vol. 64, no. 1-2, pp. 251-263, 1992.

[19] http://www.usda.gov/.

[20] F. Rasouli, A. K. Pouya, and S. A. Cheraghi, "Hydrogeochemistry and water quality assessment of the Kor-Sivand Basin, Fars province, Iran," Environmental Monitoring and Assessement, vol. 184, no. 8, pp. 4861-4877, 2012.

[21] R. Setia, P. Smith, P. Marschner, J. Baldock, D. Chittleborough, and J. Smith, "Introducing a decomposition rate modifier in the rothamsted carbon model to predict soil organic carbon stocks in saline soils," Environmental Science and Technology, vol. 45, no. 15, pp. 6396-6403, 2011.

[22] A. Lakhdar, M. Rabhi, T. Ghnaya, F. Montemurro, N. Jedidi, and C. Abdelly, "Effectiveness of compost use in salt-affected soil," Journal of Hazardous Materials, vol. 171, no. 1-3, pp. 2937, 2009.

[23] H. Bchini, M. B. Naceur, R. Sayar, H. Khemira, and L. B. KaabBettaeïb, "Genotypic differences in root and shoot growth of barley (Hordeum vulgare L.) grown under different salinity levels," Hereditas, vol. 147, no. 3, pp. 114-122, 2010.

[24] Stand Management and Natural Hazards Unit, http://eusoils.jrc.ec.europa.eu/, Joint Research Centre-The European Commission's in-house science service, http://ec.europa.eu/ dgs/jrc/index.cfm, and Institute for Environment and Sustainability (IES), http://ies.jrc.ec.europa.eu/, European Commission, March 2012.

[25] M. Qadir and J. D. Oster, "Crop and irrigation management strategies for saline-sodic soils and waters aimed at environmentally sustainable agriculture," Science of the Total Environment, vol. 323, no. 1-3, pp. 1-19, 2004.

[26] H. Boyko, Salinity and Aridity: New Approaches to Old Problems, The Hague, 1966.

[27] E. Epstein, J. D. Norlyn, and D. W. Rush, "Saline culture of crops: a genetic approach," Science, vol. 210, no. 4468, pp. 399404, 1980.

[28] E. Glenn, N. Hicks, J. Riley, and S. Swingle, "Seawater irrigation of halphytes for animal feed," in Halophytes and Biosaline Agriculture, Marcel Dekker, New York, NY, USA, 1995.

[29] E. Glenn, S. Miyamoto, D. Moore, J. J. Brown, T. L. Thompson, and P. Brown, "Water requirements for cultivating Salicornia bigelovii Torr. with seawater on sand in a coastal desert environment," Journal of Arid Environments, vol. 36, no. 4, pp. 711-730, 1997.

[30] Z. Aslam, A. R. Awan, M. Rizwan, A. Gulnaz, and K. A. Malik, Governmental Report on Saline Agriculture Farmer Participatory Development Project in Pakistan, Nuclear Institute for Agriculture and Biology (NIAB) Pakistan Atomic Energy Commission, Faisalabad, Pakistan, 2009.

[31] C. M. Grieve and D. L. Suarez, "Purslane (Portulaca oleracea L.): a halophytic crop for drainage water reuse systems," Plant and Soil, vol. 192, no. 2, pp. 277-283, 1997.

[32] N. P. Yensen, "Halophyte uses for the twenty-first century," in Ecophysiology of High Salinity Tolerant Plants, pp. 367-396, Springer, Berlin, Germany, 2006.

[33] E. R. Porto, M. C. C. Amorim, M. T. Dutra, R. V. Paulino, T. L. Brito, and A. N. B. Matos, "Rendimento da Atriplex nummularia irrigada com efluentes da criação de tilápia em rejeito da dessalinização de água," Revista Brasileira de Engenharia Agrícola e Ambiental, vol. 10, no. 1, pp. 97-103, 2006.

[34] I. Szabolcs, "Salt affected soils as the ecosystem for halophytes," in International Workshop on Halophytes for Reclamation of Saline Wastelands and as Resource for Livestock, Nairobi, Kenya, 1992.

[35] FAO, "Land and plant nutrition management service," http:// www.fao.org/ag/AGL/public.stm/, 2008.

[36] B. Nedjimi, Y. Daoud, and M. Touati, "Growth, water relations, proline and ion content of in vitro cultured Atriplex halimus subsp. schweinfurthii as affected by $\mathrm{CaCl} 2$," Communications in Biometry Crop Science, vol. 1, no. 2, pp. 79-89, 2006.

[37] H.-W. Koyro, N. Geissler, S. Hussin, and B. Huchzermeyer, "Mechanisms of cash crop halophytes to maintain yields and reclaim saline soils in arid areas," in Ecophysiology of High Salinity Tolerant Plants, M. A. Khan and D. J. Weber, Eds., pp. 345-366, Springer, Amsterdam, The Netherlands, 2006.

[38] E. P. Glenn, J. J. Brown, and E. Blumwald, "Salt tolerance and crop potential of halophytes," Critical Reviews in Plant Sciences, vol. 18, no. 2, pp. 227-255, 1999.

[39] http://www.seawaterfoundation.org/.

[40] R. F. Barnes and J. E. Baylor, "Forages in a changing world," in Forages: An Introduction to Grassland Agriculture, pp. 3-13, State University Press, New York, NY, USA, 1995. 
[41] J. Y. Zhang and Z. Y. WangM. A. Jenks, P. M. Hasegawa, and S. M. Jain, "Recent advances in molecular breeding of forage crops for improved drought and salt stress tolerance," in Advances in Molecular Breeding towards Salinity and Drought Tolerance, pp. 797-817, Springer, 2007.

[42] J. Brock, S. Aboling, R. Stelzer, E. Esch, and J. Papenbrock, "Genetic variation among different populations of Aster tripolium grown on naturally and anthropogenic salt-contaminated habitats: implications for conservation strategies," Journal of Plant Research, vol. 120, no. 1, pp. 99-112, 2007.

[43] G. M. Lenssen, W. E. van Duin, P. Jak, and J. Rozema, "The response of Aster tripolium and Puccinellia maritima to atmospheric carbon dioxide enrichment and their interactions with flooding and salinity," Aquatic Botany, vol. 50, no. 2, pp. 181-192, 1995.

[44] A. Debez, W. Taamalli, D. Saadaoui et al., "Salt effect on growth, photosynthesis, seed yield and oil composition of the potential crop halophyte Cakile maritima," in Biosaline Agriculture and Salinity Tolerance in Plants, pp. 55-63, 2006.

[45] B. H. Niazi, The Response of Fodderbeet to Salinity: Introduction of a Non Conventional Fodder Crop (Fodderbeet) to Salt Affected Lands of Pakistan [Ph.D. thesis], Department of Systems Ecology, Institute of Ecological Science, Faculty of Earth and Life Sciences, Vrije Universiteit, Amsterdam, The Netherland, 2007.

[46] C. Guerra, Salt Effects on Growth, Nutrient and Secondary Compound Contents of Diplotaxis tenuifolia [M.S. thesis], University of Aveiro, Aveiro, Portugal, 2008.

[47] L. F. D'Antuono, S. Elementi, and R. Neri, "Glucosinolates in Diplotaxis and Eruca leaves: diversity, taxonomic relations and applied aspects," Phytochemistry, vol. 69, no. 1, pp. 187-199, 2008.

[48] W. Szwed and K. V. Sýkora, "The vegetation of road verges in the coastal dunes of the Netherlands," Folia Geobotanica, vol. 31, no. 4, pp. 433-451, 1996.

[49] V. V. Bianco, "Rocket, an ancient underutilized vegetable crop and its potential," in Rocket Genetic Resources Network, S. Padulosi, Ed., pp. 38-60, International Plant Genetic Resources Institute, Rome, Italy, 1996.

[50] M. W. Hanson, "Hackney Marshes," Wildlife Survey and Management Plan 7, 2004.

[51] Current World Fertilizer Trends and Outlook to 2011/12, Food and Agriculture Organization of the United Nations, Rome, Italy.

[52] Biopact Towards a green energy pact between Europe and Africa, Belgium, http://news.mongabay.com/bioenergy, 2007.

[53] M. Khanna, G. Hochman, D. Rajagopal, S. Sexton, and D. Zilberman, "Sustainability of food, energy and environment with biofuels," CAB Reviews, vol. 4, no. 28, pp. 1-10, 2009.

[54] J. W. 'leary and E. P. Glenn, "Global distribution and potential for halophytes," in Halophytes as a Resource for Livestock and for Rehabilitation of Degraded Lands, Vol. 32, Tasks for vegetation science, 34, pp. 7-17, 1994.

[55] R. Murphy, J. Woods, M. Black, and M. McManus, "Global developments in the competition for land from biofuels," Food Policy, vol. 36, supplement 1, pp. S52-S61, 2011.

[56] M. Harvey and S. Pilgrim, "The new competition for land: food, energy, and climate change," Food Policy, vol. 36, no. 1, pp. 40-51, 2011.

[57] M. A. Khan, R. Ansari, B. Gul, and M. Qadir, "Crop diversification through halophyte production on salt-prone land resources," CAB Reviews, vol. 1, article 048, pp. 1-9, 2006.
[58] J. C. Callaway and J. B. Zedler, "Restoration of urban salt marshes: lessons from southern California," Urban Ecosystems, vol. 7, pp. 107-124, 2004.

[59] H. M. E. Shaer, Halophytes as Cash Crops for Animal Feeds in Arid and Semi-Arid Regions, Birkhäuser, Basle, Switzerland, 2006.

[60] L. K. Alleman and M. W. Hester, "Refinement of the fundamental niche of black mangrove (Avicennia germinans) seedlings in Louisiana: applications for restoration," Wetlands Ecology and Management, vol. 19, no. 1, pp. 47-60, 2011.

[61] B. S. Tanwar, "Saline water management for irrigation," in Proceedings of the (3rd Revised Draft) International Commission on Irrigation and Drainage (ICID '03), pp. 1-140, New Delhi, India, 2003.

[62] C. H. Keiffer and I. A. Ungar, "The effect of extended exposure to hypersaline conditions on the germination of five inland halophyte species," American Journal of Botany, vol. 84, no. 1, pp. 104-111, 1997.

[63] E. P. Glenn, J. J. Brown, and E. Blumwald, "Salt tolerance and crop potential of halophytes," Critical Reviews in Plant Sciences, vol. 18, no. 2, pp. 227-255, 1999.

[64] N. V. Fedoroff, D. S. Battisti, R. N. Beachy et al., "Radically rethinking agriculture for the 21 st century," Science, vol. 327, no. 5967, pp. 833-834, 2010.

[65] P. J. Gregory, S. N. Johnson, A. C. Newton, and J. S. I. Ingram, "Integrating pests and pathogens into the climate change/food security debate," Journal of Experimental Botany, vol. 60, no. 10, pp. 2827-2838, 2009. 

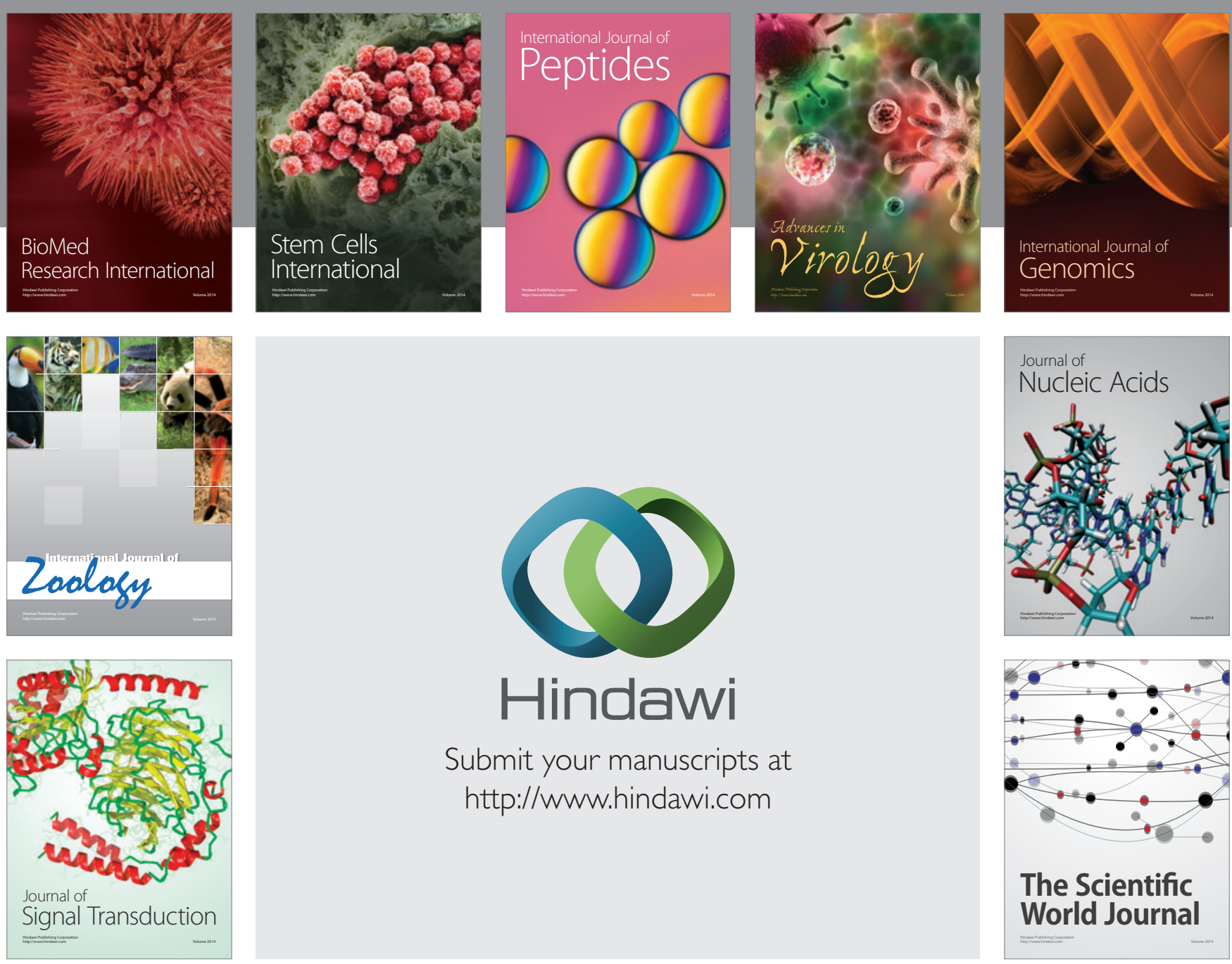

Submit your manuscripts at

http://www.hindawi.com
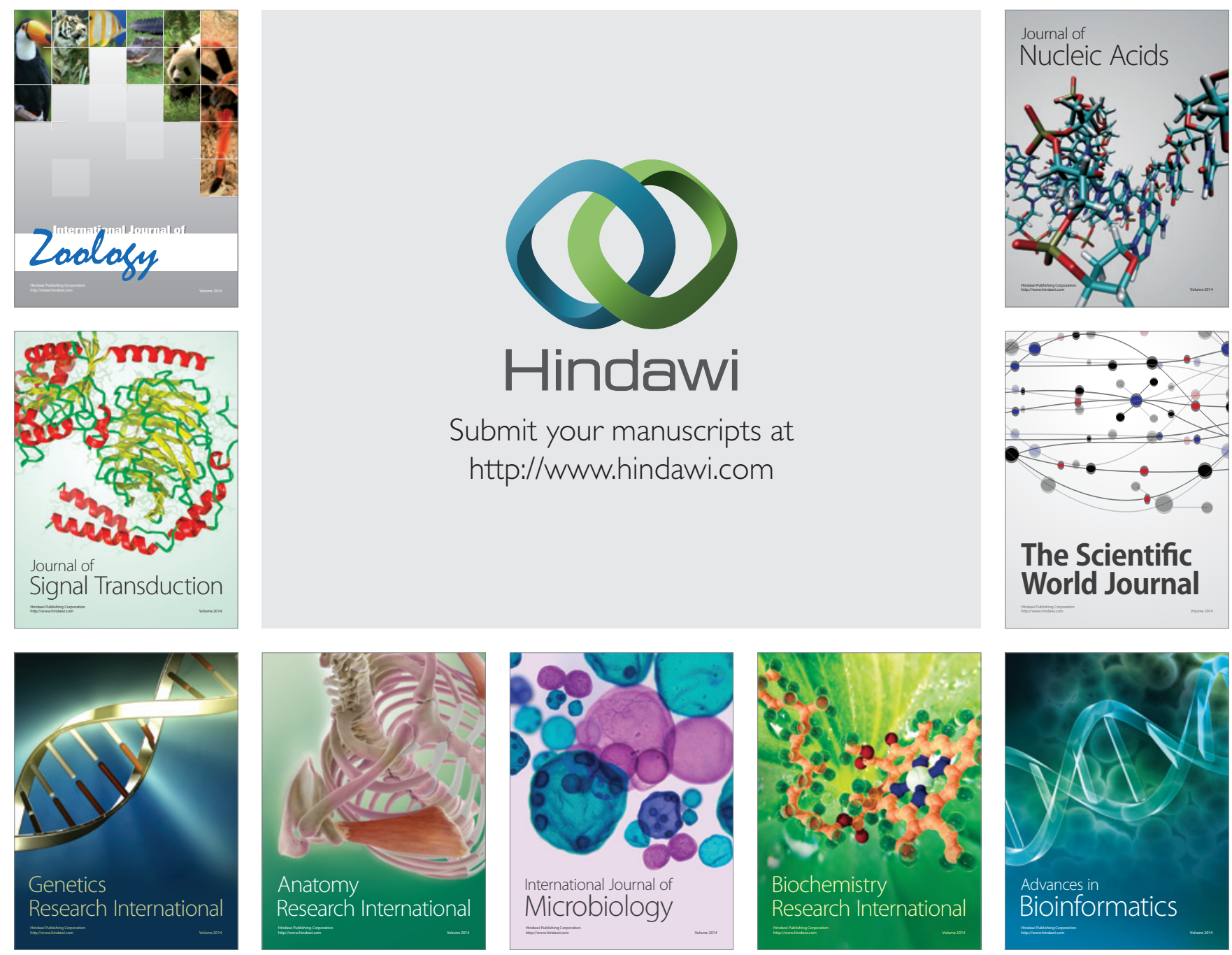

The Scientific World Journal
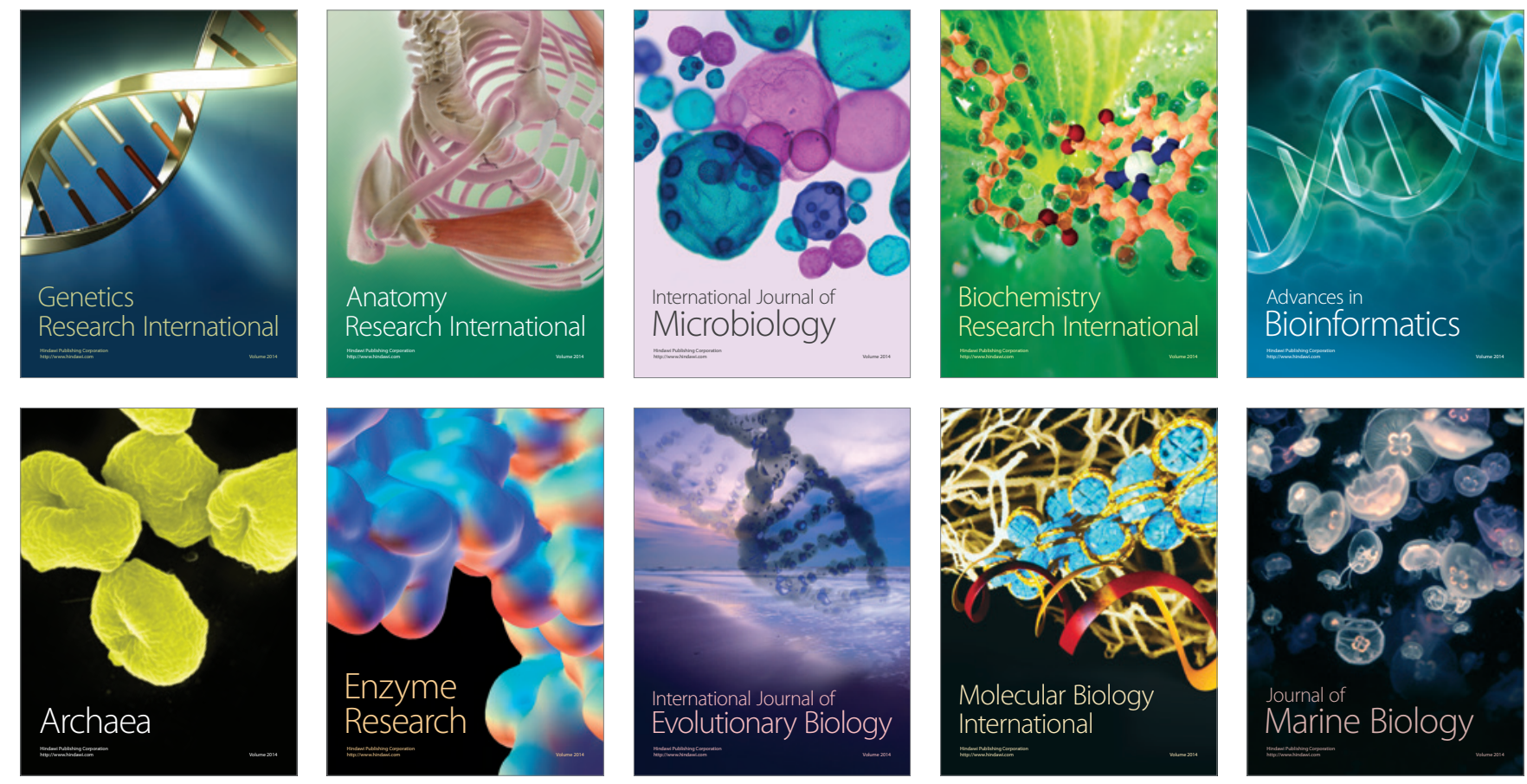